\title{
NOTES ON THE FLORA OF CHINA, II
}

\author{
SHIU-YING Hu
}

\section{With two plates}

IN 1947 K. M. Feng of the Fan Memorial Institute of Biology made a botanical expedition in southeastern Yunnan, in the region immediately east of Mengtze where A. Henry made his classical collections. From August 5 to December 20 of that year Feng collected 2985 field numbers in a relatively small area between longitude $104^{\circ}$ and $105^{\circ}$ East, on the Tropic of Cancer and a half-degree south. From working over this collection at the Arnold Arboretum it is apparent that a number of new entities are included. Below are described a new genus, Styrophyton, of the Melastomataceae, and several new species of the same family. Critical notes on other taxa in this family are recorded. The material is arranged alphabetically according to the genus and species. All the collections cited belong to the herbarium of the Arnold Arboretum.

Since the system of transliteration employed in Feng's filed labels differs from that used in the Gazetteer of Chinese Place Names based on the Index to the V. K. Ting Atlas compiled by the United States Board on Geographical Names and from that of the Map of China published in 1945 by the National Geographic Society of America, the equivalent spellings for the major localities are given below so that the reader may be helped to find the places on standard maps. After Feng's transliteration, those of the other two systems are entered with their abbreviations USB and NGS following: Ma-kuan, Ma-kuan (USB), Makwan = Anping (NGS); Mar-li-po, Ma-li-p'o (USB), Malipo (NGS); Si-chour, Hsi-ch'ou (USB), Sichow (NGS); Wen-shan, Sen-shan (USB), Wenshan = Kaihua (NGS).

Allomorphia urophylla Diels in Bot. Jahrb. 65: 102. 1932. - Li in Jour. Arnold Arb. 25: 10. 1944.

YUNNAN: Si-chour-hsien, Shiang-pyng-shan, in mixed forest by stream, alt. 1400-1500 m., K. M. Feng 11468 (shrub 5 ft. high, flower pink, common); Ma-kuan-hsien, Ching-kou (Lao-chün-shan), in open thickets, alt. 1100-1500 m., K. M. Feng 13675 (shrub $5 \mathrm{ft}$. high, fruit green, common).

As far as we know, Feng 11468 establishes the eastern and northern limit of the range of the species.

Blastus fengii sp. nov.

Frutex ca. $1.3 \mathrm{~m}$. altus, ramis subquadrangularibus, glabris, tuberculatis, ramulis junioribus squamuloso-glandulosis, glaberrimis; foliis chartaceis, junioribus glandulosis, oblongo-ovatis vel ellipticis, $8-14 \mathrm{~cm}$. longis, 4-7.5 $\mathrm{cm}$. latis, basi obtusis raro rotundatis, apice acuminatis, acumine $2 \mathrm{~cm}$. 
longo, margine integris setosisque, nervis primariis 5, marginalibus duobus tenuioribus additis, nervis transversis conspicuis, supra inter nervos sparse setosis, subtus glabris, petiolo $2-4.5 \mathrm{~cm}$. longo, squamuloso-glanduloso, glabro; cymis subsessilibus, 3-floris, ex axillis foliorum delapsorum productis; flores ignoti; pedicellis fructuum 9-12 mm. longis; capsulis subglobosis, $5 \mathrm{~mm}$. diametro (Tab. II, fig. 1), costatis 8 inconspicuis, glaberrimis, sepalis persistentibus, semi-rotundatis, $2-3 \mathrm{~mm}$. longis latisque, glabris; seminibus subovoideis, plus minusve curvatis (Tab. II, fig. 1), $0.4 \mathrm{~mm}$. longis, tuberculatis, breve rostratis.

YUNNAN: Mar-li-po, Chung-dzia, in open thickets, alt. 1800-2100 m., K. M. Feng 12726 (TYPE) (herb $3 \mathrm{ft}$. high, fruit yellowish red, common); same region, Sze-tai-po, in mixed forest, alt. 1600-2000 m., K. M. Feng 13780 (shrub 4 ft. high, flower pink, common).

In its axillary inflorescences situated at the mature portion of the stem where the leaves are often absent, and in its long pedicellate fruits with persistent roundish sepals, this species appears to be nearest to Blastus hirsutus $\mathrm{Li}$. The latter species can readily be recognized by its hirsute branchlets and fruits.

\section{Cyphotheca hispida sp. nov.}

Herba $1 \mathrm{~m}$. alta, ramis subteretibus, $2 \mathrm{~mm}$. diametro, hispidis, junioribus incanis; foliis membranaceis, oblongo-ovatis, $5.5-10 \mathrm{~cm}$. longis, $3-5 \mathrm{~cm}$. latis, basi rotundatis vel subcordatis, apice acuminatis, acumine $1 \mathrm{~cm}$. longo, margine integris hispidisque, nervis primariis 5, nervis transversis supra obscuris, subtus elevatis, supra inter nervos sparse setosis, basi glandulosohirtellis, subtus hispidis nervis praesertim, petiolo $1-5 \mathrm{~cm}$. longo, hispido; inflorescentiis subumbelliformibus cymis, terminalibus, 3- vel 4-floris, pedunculis $8 \mathrm{~mm}$. longis; flores 4-meri (Tab. II, fig. 10), pedicellis $9 \mathrm{~mm}$. longis, receptaculis subcampanulatis, hispidis; sepalis 4, ovatis, hispidis, $2 \mathrm{~mm}$. longis, acutis; petalis 4, rubris, obovatis, 8-10 mm. longis; staminibus 8 , inaequalibus, antheris incurvis, apice attenuatis, 1-porosis, thecis basi nonproductis, majoribus $5 \mathrm{~mm}$. longis, minoribus $3 \mathrm{~mm}$. longis, connectivis postice incrassatis; ovario ad receptaculum septis adnato, apice collo tubiformis laciniato laciniis glanduloso-ciliatis ornato, stylo paulo curvato, glanduloso-hirto; fructibus ignotis.

YUNNAN: Si-chour-hsien, Faa-doou, in mixed forest, alt. 1450-1550 m., K. M. Feng 11746 (TYPE) (herb $3 \mathrm{ft}$. high, flower pink, common).

The thickened connectives of the anthers of the smaller stamens, the glandular-ciliate corona at the apex of the ovary, and the hirtellous style of this species suggest a relationship with Cyphotheca montana Diels. Cyphotheca hispida can readily be distinguished from the Diels species by its hispid stem and leaves, its smaller habit, and the lack of any evident overgrowth of the thecae. The thecae of the smaller stamens of Cyphotheca montana are slightly produced at the lower front ends.

It is interesting to note that, although the form of the seeds of the 
Melastomataceae has been employed as a major character for the delimitation of the genera or sections of the family, the nature of the seeds of Cyphotheca has been lacking in botanical descriptions. It seems fitting to add here a note concerning it: Seeds numerous, subovoid-cuneate, beaked (Plate II, fig. 3 ), $0.8 \mathrm{~mm}$. long, $0.5 \mathrm{~mm}$. wide at the truncate end, the testa brown, distinctly tuberculate, the beaked side with a shiny black aril. This description is prepared from a specimen (T.T. Ÿ̈ 16627) of Cyphotheca montana Diels.

\section{Fordiophyton longipetiolatum sp. nov.}

Frutex ca. $1.3 \mathrm{~m}$. altus; ramulis glabris; foliis membranaceis, inaequalibus, lanceolatis, majoribus $9-14 \mathrm{~cm}$. longis, 3-4 cm. latis, minoribus 3-6.5 $\mathrm{cm}$. longis, 1-2 cm. latis, basi cordatis, apice acuminatis, acumine 1-2.5 $\mathrm{cm}$. longo, margine obsolete serrulatis, nervis principalibus 5 , paulo elevatis, petiolo $1-1.4 \mathrm{~cm}$. longo; inflorescentiis paniculatis; pedunculis $2-3 \mathrm{~cm}$. longis; ramis strictis patentibus, glanduloso-setulosis, bracteolatis; cymis singularibus 1- to 3-floris; bracteis cordatis, $2 \mathrm{~mm}$. longis, 2-3 mm. latis, glabris, persistentibus; floribus pedicellatis, pedicellis 4-6 mm. longis, glabris, receptaculis anguste infundibuliformibus, 6-7 mm. longis, glabris, rare 1-3 glandulosis setis; sepalis deltoideis, $2 \mathrm{~mm}$. longis, $2 \mathrm{~mm}$. latis, apice seta glandulosa; petalis rubris, apice in setulam exeuntibus; staminibus 8 , inaequalibus, antheris majoribus linearibus, $15 \mathrm{~mm}$. longis, thecarum basimus cornuto-productis, antheris minoribus oblongis, $4 \mathrm{~mm}$. longis, flavis, thecarum basibus productis; capsulis ignotis.

YUNNAN: Si-chour-hsien, Faa-doou, in mixed forests, alt. 1450-1550 m., K. M. Feng 11829 (TYPE) (shrub $4 \mathrm{ft}$. high, flower pink-rose, rare).

In general appearance this species suggests Fordiophyton strictum Diels and is probably most closely related to it. The latter species can readily be distinguished from $F$. longipetiolatum by its subsessile leaves and glandular-setose bracts and sepals.

Medinilla nana sp. nov.

Frutex humilis, 0.5-1 m. altus; ramis cinereis, rugosis et verruculosis; ramulis quadrangularibus, brunneis, internodiis $1-3 \mathrm{~cm}$. longis, alatis, axillis foliorum setis sparse vestitis; foliis coriaceis, obovatis, $1-2.3 \mathrm{~cm}$. longis, 0.7-1.7 cm. latis, paucidenticulatis, ad apicem 2 vel 3 dentibus minutis, basi obtusis, apice rotundis et retusis, costa supra impressa, subtus elevata, nervis lateralibus obscuris, petiolo $1-3 \mathrm{~mm}$. longo; inflorescentiis terminalibus, solitariis vel cymosis simplicibus, cymis 2-floris; pedunculis $5 \mathrm{~mm}$. longis; bracteis ovatis, glanduloso-erosis; pedicellis 2-3 $\mathrm{mm}$. longis; flores ignoti; baccis oblongo-subglobosis, $8 \mathrm{~mm}$. longis, $6 \mathrm{~mm}$. diametro; sepalis persistentibus rotundatis, erosis et glandulosis; seminibus numerosis, minutis, ovoideis, $1 \mathrm{~mm}$. longis, 4-5 $\mathrm{mm}$. diametro, testis reticulatis.

YUNNAN: Si-chour-hsien, Faa-doou, in mixed forest, alt. 1500-1600 m., K. M. Feng 11920 (shrub $1 \mathrm{ft}$. high, fruit green, common); Mar-li-po, Chung- 
dzai, in mixed forest, alt. 1600-1800 m., K. M. Feng 12784 (TYPE) (shrub $3 \mathrm{ft}$. high, fruit green, common).

I can suggest no close relative for this very distinct species. Its broadly winged paired branchlets, its small obovate paucidenticulate coriaceous leaves, and its terminal solitary flowers or simple cymes are unlike any known species of Medinilla. Nevertheless, the fleshy berries with their thin calyx tube and exterovarial chambers place the species in Bakhuizen's section Hetero-Medinilla of this genus. The small ovoid seeds with their reticulate testas suggest relationship to Pachycentria fengii S. Y. Hu.

Medinilla petelotii Merr. in Univ. Cal. Publ. Bot. 13: 137. 1926.

YUNNAN: Si-chour-hsien, Ting-mann, in mixed forests, alt. 1300-1500 m., K. M. Feng 12334 (scandent shrub 5 ft. high, flowers pink-rose, rare); Mar-li-po, Huang-jin-in, in mixed forests, alt. 1300-1400 m., K. M. Feng 13063 (shrub $5 \mathrm{ft}$. high, flowers lavender, rare); same region, Sze-tai-po, Loa-chün-shan, in mixed forest, alt. 1300-1500 m., K. M. Feng 13946 (shrub $4 \mathrm{ft}$. high, fruit green, common).

Feng 13063 fits Merrill's description well, and it matches the photograph of Pételot 1791 (type of Medinilla petelotii Merr.) in every respect. The fertile portion of Feng 12334 appears to have been a section from the lower part of a creeping stem. It has many fibrous adventitious roots. The inflorescences on such a stem are much more ramified and also appear longer than the typical ones as represented by Pételot 1791 and Feng 13063. With all other aspects identical, I am inclined to think that the larger inflorescence is due to the vigor of the plant.

Tsai 60315 from Ping-pien-hsien, Yunnan, appears to belong here.

Melastoma normale D. Don, Prodr. Fl. Nepal. 220, 1825. - Rehd. \& Wils, in Sarg. Pl. Wils. 2: 421. 1915. - Li in Jour. Arnold Arb. 25 : 8. 1944.

YUNNAN: Si-chour-hsien, Faa-doou, in open thickets on rock, alt. 14501550 m., K. M. Feng 11870 (shrub 4 ft. high, fruit green-yellow, common); Mar-li-po, Sze-tai-po (Loa-chün-shan), in open thickets by stream, alt, 11001300 m., K. M. Feng 14053 (herb 3 ft. high, flowers pink-purple, common).

Feng's designation of the habit of the plant as represented by his number 14053 does not seem to be appropriate, for our specimen of this number exhibits a strong woody third-year stem. In the herbarium this species is often confused with Melastoma candidum D. Don, and in botanical literature the diagnostic characters given are rather inadequate, since they were drawn from the indumentum of the stem and the shape of the leaf-base. Both of these characters vary with the ecological conditions under which the plant grows and the age and vigor of the plant. Melastoma normale D. Don is generally recorded as, "stem with long spreading hair, leaves with round and obtuse base," and Melastoma candidum D. Don as "stem with appressed scale-like hairs and leaves with subcordate bases." Round and subcordate bases are sometimes very hard to distinguish, and 
the spreading hairs are so coarse and dented that they appear scaly. Detailed examination of our material seems to reveal two constant characters that can be employed in the diagnosis of these two species. In Melastoma normale D. Don the sepals are linear-lanceolate and the anterior lobes of the connectives of the large stamens are small, round, and almost undivided, while in Melastoma candidum D. Don the sepals are broad deltoid and the anterior lobes of the connectives of the large stamens are pointed and over $2 \mathrm{~mm}$. long. In general Melastoma normale D. Don has lanceolate leaves and smaller globose fruits, and the leaves of Melastoma candidum D. Don are ovate and the fruits larger and oblong.

Osbeckia chinensis Linn. Sp. Pl. 345. 1754. - Li in Jour. Arnold Arb. 25: 4. 1944.

YUNNAN: Si-chour-hsien, Faa-doou, on open grassy slopes, alt. 1450-1550 m., K. M. Feng 11765 (herb 3-10 in. high, flowers pink, common).

This is probably the most widely distributed species of the Melastomataceae in China. It occurs in the coastal region from Foochow to Hongkong and thence westward over all the warm temperate region of China. It can readily be recognized by (1) the small herbaceous habit; (2) the lanceolate leaves; (3) the terminal simple cymes; (4) the stellate tufted calyx tubes; (5) the persistent corona of rigid hairs at the apex of the ovary; and (6) the glabrous urn-shaped fruits. The vernacular name "t'ien-hsiang-lu" (heavenly incense burner) is a very good connotation of the characteristic fruit.

Oxyspora paniculata DC. Prodr. 3: 123. 1828. - Li in Jour. Arnold Arb. 25: 12. 1944.

YUNNAN: Wen-shan-hsien, Hwang-tsao-bah, by streams on scrub, alt. 1600 m., K. M. Feng 11011 (herb $2 \mathrm{ft}$. high, flowers lavender-red, common); Si-chourhsien, Shiang-pyng-shan, in mixed forests by streams, alt. 1400-1500 m., K. M. Feng 11472 (shrub $5 \mathrm{ft}$. high, flower rose-pink, common); Mar-li-po, Sze-tai-po (Loa-chün-shan), in open thickets by streams, alt. 1300-1500 m., K. M. Feng 14037 (shrub $3 \mathrm{ft}$. high, flower rose-pink, common).

Oxyspora paniculata DC. is the type species of the genus. It has very unique seeds, the form of which is so characteristic that I have not seen the like in any other Asiatic genus of the Melastomataceae. The embryo proper is straight, club-shaped, or subovoid. The testa is so produced that the seed appears cuneate. It is beaked on the aril side of the truncate end, and opposite the beak there is a distinct spur which is longer than the beak. In a profile view the seed appears like the head of an adze (Plate II, fig. 4).

Pachycentria fengii sp. nov.

Frutex sempervirens, epiphyticus, scandens, ramulis teretibus, glabris, fusco-rubescentibus, extimis compressis, lenticellis albis, prominentibus; foliis subcoriaceis, integerrimis, obovatis, $3.5-8.5 \mathrm{~cm}$. longis, $2-3.5 \mathrm{~cm}$. 
latis, basi cuneatis vel obtusis, apice acuminatis, acumine $5-10 \mathrm{~mm}$. longo, obtuso, trinerviis, nervis supra planis, subtus elevatis, reticulis obscuris, petiolo 6-10 $\mathrm{mm}$. longo, glabro; flores ignoti; inflorescentiis fructiferis corymbosis, laxis, terminalibus; pedunculis $1-1.7 \mathrm{~cm}$. longis; pedicellis 5 $\mathrm{mm}$. longis; baccis urceolatis, 6-7 $\mathrm{mm}$. longis, 4-5 mm. diametro (Tab. II, fig. 5-7); sepalis persistentibus deltoideis, apice postice minutis uncis instructis; seminibus numerosis, minutis, ovoides, $1 \mathrm{~mm}$. longis, $0.7 \mathrm{~mm}$. diametro, testis reticulatis (Tab. II, fig. 8).

YUNNAN: Si-chour-hsien, Faa-doou, on trees in mixed forest, alt. 1500-1550 m., K. M. Feng 11789 (TYPE) (shrub $4 \mathrm{ft}$. high, fruit green, pedicel red, common).

Pachycentria Blume was first discovered in Java. The center of its distribution is the Malay Archipelago. Hayata in 1912 described a species from Formosa and Ridley in 1915 published another one from the Malay Peninsula. Pachycentria fengii S. Y. Hu seems to be the first species recorded from the Chinese mainland. It sets the northern limit for the genus. To Blume, Pachycentria differs from Medinilla in: "1) tubo calycis sursum cyathiformi-dilatati circa ovarium fortius constricto; 2) petalis acuminatis; 3) staminum structura diversa, quum antherarum connexivum in Medinillis omnibus ad basin antice auriculas duas et postice calcar subulatum exserat, hic autem tantummodo postice calcari parvo crassiusculo muniatur." Bakhuizen f. regarded the degree of union of the ovary with the calyx tube to be more significant for the generic delimitation. He maintained that in Pachycentria the ovary is "wholly concrescent with the calyx tube," while in Medinilla it is "adnate to the calyx tube with longitudinal septs." The calyx tubes of the Formosan and the Chinese material are not so much constricted as those of the Malaysian species. Nevertheless, the connection between the ovary and the calyx tube is complete. There does not seem to be any doubt that our material is a species of Pachycentria.

Phyllagathis wenshanensis sp. nov.

Herba, caulibus petiolisque dense longe crispo-hirsutis, rhizomate prostrato, ramis teretis, $5 \mathrm{~mm}$. diametro; foliis valide membranaceis, orbicularibus, 5-7 cm. longis latisque, olivaceo-viridibus, basi perspicue cordatis, apice rotundatis et plerumque emarginatis, nervis primariis 5 vel 7, nervis transversis supra obscuris, subtus perspicuis et dense crispohirsutis, margine integris et ciliatis, supra disperse breve setosis et molliter crispo-hirtis, subtus hirsutis, nervis dense crispo-hirsutis, petiolo 2.5-4.5 $\mathrm{cm}$. longo; inflorescentiis umbellatis, terminalibus, 4-floris, pedunculis $11 \mathrm{~cm}$. longis, hirtellis; flores ignoti; pedicellis fructuum $1 \mathrm{~cm}$. longis, hirtellis; calycibus persistentibus deltoideis, acutis; capsulis turbinatis, hirtellis, $5 \mathrm{~mm}$. longis; apice $5 \mathrm{~mm}$. diametro, placenta supra ramificata, seminibus ovoideis, $0.8 \mathrm{~mm}$. longis, $0.4 \mathrm{~mm}$. diametro, truncatis, tuberculatis, breve rostratis.

YUNNAN: Wen-shan-hsien, Lao-jiun-shan, in mixed forest, alt. $2300 \mathrm{~m}$., K. M. Feng 11186 (TYPE) (herb 4 in. high, fruit greenish, rare). 
The creeping habit and rounded leaves of this species suggest a relationship with Phyllagathis cavaleriei (Lévl. \& Van.) Guill., which has glabrous capsules and leaves with long setose hairs.

Plagiopetalum henryi (Kränzl.) comb. nov.

Barthea cavaleriei Lévl. in Fedde, Rep. Spec. Nov. 8: 61. 1910, pro parte, quod Esquirol 215.

Sonerila henryi Kränzl. in Viert. Nat. Ges. Zürich 76: 152. 1931.

Plagiopetalum esquirolii sensu Li, in Jour. Arnold Arb. 25: 10. 1944, non Rehder.

YUNNAN: Wen-shan-hsien, Pyng-bah, moist sandy margin of mixed forest, alt. 1700 m., K. M. Feng 11028 (shrub 2 ft. high, flower pinkish-red, rare); Marli-po, Pan-chia-chü, roadside, alt. 1800-2100 m., K. M. Feng 12674 (shrub 3 ft. high, fruit red, common).

Regarding Plagiopetalum Rehder stated, "In its floral structure it seems nearest to Sonerila, but that genus is easily distinguished by its trimerous flowers and symmetrical petals." If Plagiopetalum is accepted as a genus at all, then the transfer of Sonerila henryi Kränzl. is justified because of its tetramerous flowers and asymmetrical petals. $\mathrm{Li}$ (1944) interpreted Sonerila henryi Kränzl. and Plagiopetalum esquirolii (Lévl.) Rehd. to be conspecific. After detailed examination of the materials at hand, including Wilson 3261, the type of Plagiopetalum quadrangulum Rehder which, in turn is the type species of the genus and has been interpreted by both Diels and Rehder as synonymous with Plagiopetalum esquirolii (Lévl.) Rehder, I find it hard to accept this view. Plagiopetalum esquirolii (Lévl.) Rehd., as typified by Wilson 3261, represents a plant devoid of scabrous hairs on the petioles, peduncles, pedicels and receptacles, while these parts of the specimens that I designated as Plagiopetalum henryi (Kränzl.) S. Y. $\mathrm{Hu}$ are scabrous.

When Léveillé published Barthea cavaleriei he cited three specimens, namely Cavalerie 1552 and Esquirol 215 and 1581 . He designated no type. Diels (1932) segregated Cavalerie 1552 and transferred it to Bredia. Here in our herbarium there is a photograph and a good fragment of Esquirol 215 which is identical with A. Henry 9077, an isotype of Sonerila henryi Kränzl. Since Barthea cavaleriei Lévl. is a synonym of Bredia cavaleriei (Lévl.) Diels, the next published specific name, is here adopted.

The seed of Plagiopetalum henryi (Kränzl.) S. Y. Hu has a very unique form. It is oblong in outline, $1 \mathrm{~mm}$. long, $0.5 \mathrm{~mm}$. in diameter, obscurely papillate, and appendaged on three sides (Plate II, fig. 11).

Sarcopyramis bodinieri Lévl. \& Van. in Mem. Soc. Nat. Sci. Nat. Cherbourg. 35 : 397. 1906; et in Fedde, Rep. Spec. Nov. 4: 95. 1907.

Sarcopyramis nepalensis var. bodinieri (Lévl. \& Van.) Lévl., Fl. Kouy-Tchéou 278. 1914.

Sarcopyramis nepalensis sensu Diels in Bot. Jahrb. 65: 111. 1932. - Li in Jour. Arnold Arb. 25: 25. 1944, non Wallich. 
YUNNAN: Wen-shan-hsien: Loa-jiun-shan, in mixed forest, alt. $2300 \mathrm{~m}$., $K$. M. Feng 11188 (herb 3 inches high, leaves green above, purple below, fruits green and purple, common).

Sarcopyramis bodinieri Lévl. \& Van. has been misinterpreted by several authors as Sarcopyramis nepalensis or its variety. Additional material in the flowering stage reveals certain characters which prove such a concept to be wrong. The type sheet of Sarcopyramis bodinieri Lévl. \& Van. (E. Bodinier 2393) contains five specimens, four with small colored leaves and one with larger green leaves. Guillaumin (Bull. Soc. Bot. France 60: 343. 1913) suggested that the plants might represent a smaller form of $S$. napalensis Wall. Léveillé, without giving any reason, published it (1914) as such. Diels (1932) actually sank it into the synonymy of Sarcopyramis nepalensis, and his view has been accepted by later authors. In Feng 11188 we have five plants which match the small plants of the holotype of Sarcopyramis bodinieri Lévl. \& Van. Careful examination of these specimens as well as of the fragments of Bodinier 2393 reveals that besides the smaller size of the plants and the purple color of the foliage there are certain floral characters which distinguish them as a distinct species. In Sarcopyramis napalensis Wall. the bracts are ovate, acute, the calyx lobes are truncate and ciliate, and the anthers are subelliptic with the notched apical ends slightly pointed. In Sarcopyramis bodinieri Lévl. \& Van. the bracts are spathulate, the calyx lobes are eciliate, each with two horn-like projections, and the anthers are obcordate, each not much longer than the upward spur on the posterior side of the connective. The leaves of Sarcopyramis bodinieri Lévl. \& Van. are sparsely setose above and glabrous beneath with an acute apex, while those of Sarcopyramis napalensis Wall. are elliptic or ovateelliptic with an acuminate apex. Judging from the shape, the texture and the pubescence of the leaves, and the horned calyx lobes, Sarcopyramis bodinieri Lévl. \& Van. is nearer to the Kwangsi specimens which have been named as Sarcopyramis delicata C. B. Rob. than to Sarcopyramis napalensis Wall. All specimens of the Kwangsi material have solitary flowers. $C$. $Y$. Chiao 1304 from Ya-an, Sikang, with small ovate leaves and umbellate inflorescences, definitely belongs here.

Sarcopyramis napalensis Wall., Tent. Fl. Napal. 32, pl. 23. 1824. Li in Jour. Arnold Arb. 25: 25. 1944.

YUNNAN: Mar-li-po, Sze-tai-po (Lao-chün-shan), in mixed forest, alt. 13001500 m., K. M. Feng 13974 (herb 4 in. high, fruit green, common).

Sonerila cantonensis Stapf in Ann. Bot. 6: 302. 1892. - Li in Jour. Arnold Arb. 25 : 35. 1944.

YUNNAN: Si-chour-hsien, Faa-doou, in mixed forest, alt. 1500-1550 m., K. M. Feng 11877 (Herb $1 \mathrm{ft}$. tall, flower pink-rose).

This species has been recorded from Kwangtung, Kwangsi, and Fukien. This is a new record for the flora of Yunnan. 
Sonerila yunnanensis J. Jeffrey in Notes Bot. Gard. Edinb. 8: 207. 1914.

YUNNAN: Si-chour-hsien, Ting-mann, on cliffs in mixed forests, alt. 11001200 m., K. M. Feng 12349 (herb 4 in. high, fruit green, rare).

Jeffrey described the seeds of this species as "seminibus ovoideis minute punctulatis." This is true. But on closer examination of Feng 12349 as well as of Henry 12337, the latter an isotype of the species, a very interesting character is revealed, concerning which it is worth while to add a note. This character is the presence of a two-lobed bladder at the apical end of the seed opposite the shiny dark brown aril (Plate II, fig. 9). Seeds of Sonerila cantonensis Stapf, Sonerila hainanensis Merr., Sonerila picta Korth., and Sonerila tenera Royle were also examined for comparison. With the exception of Sonerila tenera Royle, all these species have seeds with the bladder at the apical end of the aril side. This character correlates with the attenuated anther and the funnel-shaped fruit. One must conclude that such a character is at least subgenerically distinct.

\section{Stapfiophyton erectum sp. nov.}

Herba erecta, $0.75 \mathrm{~m}$. alta, ramis subteretibus, $5 \mathrm{~mm}$. diametro, cinereis, junioribus furfuraceis; foliis subcoriaceis, glabris, ellipticis, 10-12 cm. longis, $3.5-5 \mathrm{~cm}$. latis, basi obtusis, apice caudato-acuminatis, acumine 1.5-2 $\mathrm{cm}$. longo, subtus glandulosis, nervis primariis 3, marginalibus duobus tenuioribus additis, nervis transversis supra obsoletis, subtus conspicuis, margine integro; petiolo $1.5-2.5 \mathrm{~cm}$. longo, glanduloso, glabro; inflorescentiis subumbelliformi-cymis, paniculatis, terminalibus, pedunculis $3 \mathrm{~cm}$. longis, cymis 3-vel 4-floris, pedicellis 4-5 mm. longis, glabris; flores ignoti; capsulis subturbinatis, 3-4 mm. diametro, apice depressis, placenta supra ramificata, seminibus ad basim adnatis; seminibus ovoideis, $0.7 \mathrm{~mm}$. longis, $0.4 \mathrm{~mm}$. diametro, rostratis, testa papillata.

YUNNAN: Mar-li-po, Huang-jin-in, in mixed forest, alt. 1300-1500 m., K. M. Feng 13082 (TYPE) (herb $2 \mathrm{ft}$. high, fruit whitish yellow, common).

By its ramified placenta this species can be placed either in Phyllagathis Blume or Stapfiophyton Li. It is because of its paniculate cymose inflorescences that the latter is chosen.

\section{Styrophyton gen. nov.}

Anerincleistus ? sensu Diels in Bot. Jahrb. 65: 101. 1932, non Korthals.

Allomorphia sensu Li in Jour. Arnold Arb. 25: 11. 1944, non Blume.

Inflorescentiae spicatae (Tab. I, fig. 1), floribus sessilibus, 4-meris; receptaculis subcampanulatis, strigosis; sepalis brevibus; petalis unguiculatis (Tab. I, fig. 5); staminibus 8, subaequalibus, antheris rectis, apice paulo attenuatis, 1-porosis, thecis antice basi paulo productis, connectivo postice non aucto, ovario basi receptaculi adnato, stylo attenuato, basi setis ornati, stigmate capitato. Fructus ovoideo-subglobosus, costis pallidis et prominentibus, quadrilocularibus; semina numerosa, minuta, cuneata, 
truncata et rostrata. Frutices, ramis dense tomentosis; foliis magnis, ovatis, petiolatis.

TyPE SPEcIES: Styrophyton caudatum (Diels) S. Y. Hu.

In all recent monographic work on Melastomataceae the inflorescences, whether they are panicles, umbels, scorpioid cymes, or otherwise, have been used as key characters for generic demarcations. Diels in 1932 first saw Henry 10761, a specimen from Yunnan with a spicate inflorescence. Realizing that it was unique, he described it as new, and probably because of its superficial resemblance to Anerincleistus Beccarii Cogn., he doubtfully assigned it to Anerincleistus Korthals. Li in 1944, on the basis of the prominent striation of the fruits, transferred Diels' species to Allomorphia Blume and added a description of the immature fruit and seed. With mature fruit from Feng's southeastern Yunnan collection I made careful dissections of the flower of Henry 10761 (isotype), the young fruit of Tsai 61591, and the mature fruit of Feng 12291, and compared each with those of Anerincleistus Korthals and Allomorphia Blume. After a review of all the literature concerning these two genera and a detailed examination of all the material in the Arnold Arboretum and the Gray Herbarium, I feel that the southeastern Yunnan plant is generically distinct. Besides the simple unramified spicate inflorescence, which at once distinguishes it from the paniculate type found in Allomorphia Blume, the short calyx tube is also very distinct. In Allomorphia Blume the calyx tube is tubular, at least twice as long as wide, and with the ovary attached only at its base. Consequently, in fruit, the free portion of the persistent calyx tube forms a tall collar, which is usually constricted at the base. Moreover, at the apex of the ovary in Allomorphia there is no appendage such as bristles or corona, and consequently the apical end of a mature fruit is smooth and concave. In Styrophyton the calyx tube (Plate I, fig. 6) is only slightly longer than wide, and in fruit it does not form an evident collar (Plate I, fig. 2). Moreover, the persistent bristles at the apex of the ovary render the apical end of the mature fruit rough. The cuneate, truncate, and beaked seed and the striate fruit of Styrophyton indicate a close relationship with Allomorphia Blume on the one hand, and its short calyx tube and the rough apical end of the fruit show affinity with Anerincleistus Korthals on the other hand. These characters, together with the true spicate inflorescence, constitute my reasons for proposing a new genus whose natural position lies between Allomorphia Blume and Anerincleistus Korthals. Species of the latter genus can easily be distinguished by their pedicellate flowers, paniculate inflorescences, prominent corona at the apex of the ovary, and smooth capsules with persistent corona exposed at the apical end of the fruit.

Regarding the fruit and seed characters of this taxon Li (1944) recorded, "The somewhat immature fruits are ... one-celled.. . seeds very minute, oblong." This is far from correct. Both the cross- and the longitudinal sections of the mature, as well as the young fruit, appear to have four cells (Plate I, figs. $3 \& 4$ ). The seed of the mature fruit is oblong- 
cuneate, $0.6-0.7 \mathrm{~mm}$. long, $0.3-0.4 \mathrm{~mm}$. in diameter, indistinctly ridged, truncate and beaked, slightly grooved on the beaked side and appendaged at the proximal end (Plate I, fig. 7). The testa is brown and smooth.

Styrophyton caudatum (Diels) comb. nov.

Anerincleistus? caudatus Diels in Bot. Jahrb. 65: 101. 1932.

Allomorphia caudata (Diels) Li in Jour. Arnold Arb. 25: 11. 1944.

YUNNAN: Si-chour-hsien, Ting-mann, in mixed forests, alt. 1200-1300 m., K. M. Feng 12291 (shrub $6 \mathrm{ft}$. high, young fruit green, common). Other specimens that I have examined are: A. Henry 10761 (ISOTYPE) from Mengtze, H. T. Tsai 60437, 60563, 61279, and 61591, all from Ping-pien hsien of Yunnan.

This species is a shrub which grows up to 5 meters high. In southeastern Yunnan it occurs in mixed forests at altitudes varying from 1000 to 1500 meters. The distribution is rather limited. So far, specimens have been collected only from the southeastern region of Yunnan between Long. $103^{\circ}$ and $105^{\circ} \mathrm{E}$. and Lat. $22^{\circ} 50^{\prime}$ and $23^{\circ} 30^{\prime} \mathrm{N}$. Our material exhibits very little variation even in the vegetative characters. Compared with the isotype, the base of some leaves may be subcordate rather than round, occasionally the upper surface of the leaves may be more or even less verruculose, the pubescence on the lower surface may be brown rather than white, and between these hairs there may be fewer glands. It seems that all these variations may be attributed to the age of the plants, the size of the leaves, or even to the pressing and drying processes in the preparation of the specimens.

\section{EXPLANATION OF PLATES}

\section{Plate I}

Styrophyton caudatum (Diels) S. Y. Hu: Fig. 1. A fruiting branch $(\times 1 / 2)$, the indumentum omitted. FIG. 2. A fruit $(\times 5)$. Fig. 3. The same, longitudinal section, lower portion not through the center of the fruit $(\times 10)$. Fig. 4. Crosssection of a young fruit $(\times 10)$. Fig. 5. A flower $(\times 5)$. Fig. 6. The same with part of the calyx tube, petals and stamens removed $(X 5)$. Fig. 7. Some seeds $(\times 12)$.

\section{Plate II}

FIg. 1. Fruit of Blastus fengii S. Y. Hu $(\times 3)$, with seeds in lateral view $(\times 10)$. Fig. 2. Habit sketch of Medinilla nana S. Y. Hu $(\times 2)$, with seeds $(\times 10)$. Fig. 3. Seed of Cyphotheca montana Diels $(\times 10)$, side and front views. Fig. 4. Seed of Oxyspora paniculata DC. $(\times 12)$. Fig. 5. Longitudinal section of the fruit of Pachycentria fengii S. Y. Hu $(\times 6)$. FIG. 6. Fruit of the same $(X 5)$, with persistent calyx, each lobe of which has a small hook on the back. Fig. 7. Cross-section of the ovary of the same, diagrammatic. Fig. 8. Seeds of Pachycentria fengii S. Y. Hu $(\times 5)$. Fig. 9. Seeds of Sonerila yunnanensis J. Jeffrey $(\times 10)$. Fig. 10. A flower of Cyphotheca hirsuta S. Y. Hu $(\times 3)$, with 1 petal and 1 smaller stamen removed. FIg. 11. Seed of Plagiopetalum henryi (Kränzl.) S. Y. Hu (X 10).

Arnold Arboretum,

HARVARD UNIVERSITY. 


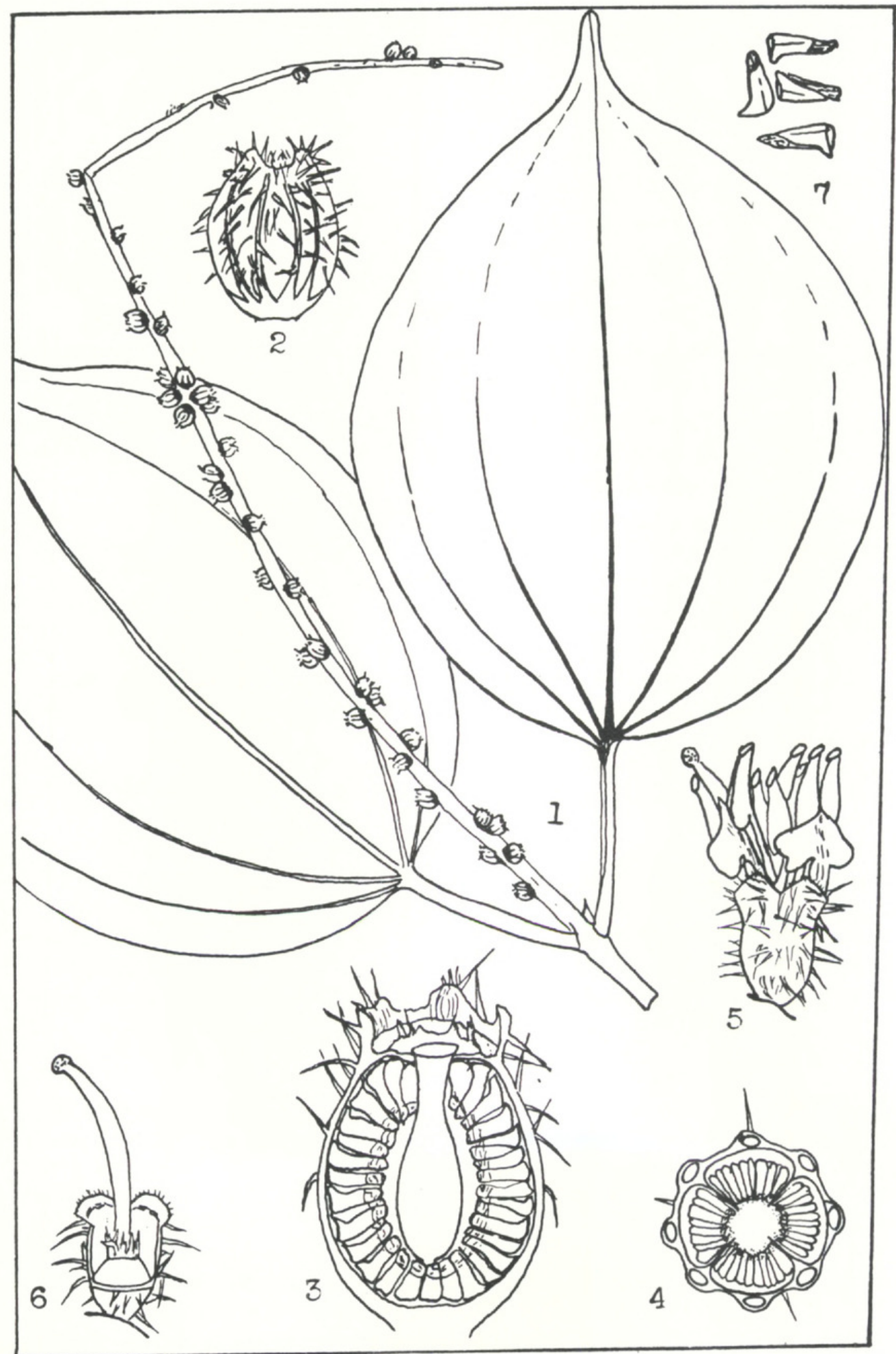

Hu, Notes on the Flora of China, II 

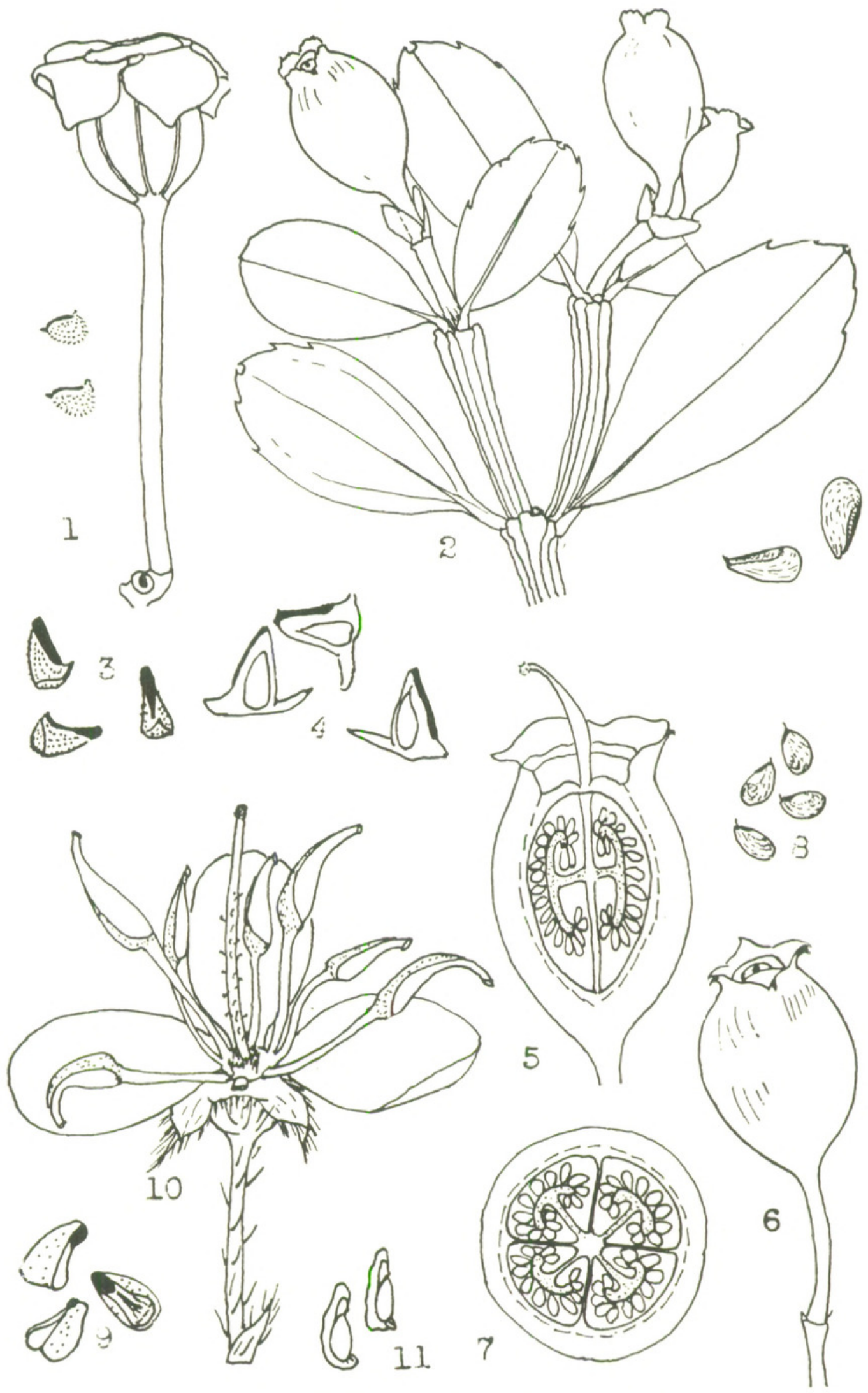

Hu, Notes on the Flora of China, II 


\section{$2 \mathrm{BHL}$ Biodiversity Heritage Library}

Hu, Shiu-Ying. 1952. "Notes on the Flora of China, II." Journal of the Arnold Arboretum 33(2), 166-178. https://doi.org/10.5962/p.185811.

View This Item Online: https://www.biodiversitylibrary.org/item/33609

DOI: https://doi.org/10.5962/p.185811

Permalink: https://www.biodiversitylibrary.org/partpdf/185811

\section{Holding Institution}

Missouri Botanical Garden, Peter H. Raven Library

\section{Sponsored by}

Missouri Botanical Garden

\section{Copyright \& Reuse}

Copyright Status: In copyright. Digitized with the permission of the rights holder.

Rights Holder: Arnold Arboretum of Harvard University

License: http://creativecommons.org/licenses/by-nc-sa/3.0/

Rights: https://biodiversitylibrary.org/permissions

This document was created from content at the Biodiversity Heritage Library, the world's largest open access digital library for biodiversity literature and archives. Visit BHL at https://www.biodiversitylibrary.org. 